Personalidade Acadêmica Homenageada:

Raymundo Juliano Feitosa (Universidade Federal do Rio Grande do Norte - UFRN)

\title{
MUSEU NACIONAL - ESTUDO DE CASO ACERCA DAS OBRIGAÇÕES DO ESTADO DECORRENTES DO TOMBAMENTO
}

\section{NATIONAL MUSEUM - CASE STUDY ABOUT STATE OBLIGATIONS ARISING FROM TOMB}

JULIANA VIEIRA PELEGRINI

Mestranda do Centro Universitário Curitiba - UNICURITIBA. Curitiba - PR. E-mail: juliana.vieirapelegrini@gmail.com

\section{RESUMO}

O tema do presente estudo em tela, visa abordar a obrigação da Administração Pública em relação ao instituto do tombamento e em específico no caso do incêndio ocorrido no Museu Nacional no mês de setembro no Rio de janeiro do presente ano. O artigo irá questionar o Dec- Lei 25 de 30.11.37 e as restrições que são impostas no tombamento de bens históricos vigentes, em específico no artigo 17 e analisar as obrigações em relação à União na preservação de patrimônios tombados presentes no atrigo 19 em seu parágrafo. Será questionado no decorrer do artigo se a Administração Pública foi falha e negligente em relação ao dever de preservar o patrimônio histórico cultural, no caso o Museu Nacional e se ocorreu negligencia por parte do Poder Público, o que pode ser aletrado, modificado, implementado para que esse tipo de tragédia não ocorra mais em nosso país. A preservação do patrimônio histórico, e o consequente tombamento de bens materiais e imateriais, visa preservar a memória de uma coletividade e, dessa forma, fornecer elementos que permitam a essa coletividade desenvolver e sustentar seu senso de continuidade e identidade na temporalidade histórica. No Brasil, as políticas voltadas à preservação do patrimônio remontam ao início do século XX, tendo sido consolidadas na década de 1930 por 


\section{Personalidade Acadêmica Homenageada:}

Raymundo Juliano Feitosa (Universidade Federal do Rio Grande do Norte - UFRN)

meio do Decreto Lei oㅡ 25/1937 que estabelece normas gerais para o tombamento e que foi, posteriormente, complementado por outros instrumentos legais, tais como a Constituição Federal de 1988 e o Estatuto das Cidades. Além dos instrumentos legais, recursos institucionais, que se consubstanciam no Instituto do Patrimônio Histórico e Artístico Nacional (IPHAN), complementam o arcabouço jurídico-institucional voltado à preservação do patrimônio histórico no Brasil. O instituto do tombamento, considerado, à princípio, um instrumento benéfico à sociedade, pois visa à sua própria preservação e continuidade no tempo, e quando bem administrado, contribui para o seu desenvolvimento socioeconômico, não se dá, entretanto, sem conflitos e paradoxos. Há, de fato, que se preservar, mas, até que ponto os instrumentos de preservação podem ser prejudiciais à própria preservação? Até que ponto a lei, em razão de sua rigidez, é um entrave para a preservação do patrimônio? Quais atores são responsáveis pelo patrimônio e qual é a reponsabilidade do Estado, no âmbito administrativo, nesse sentido? Quem define, por meio do tombamento, o que deve ser preservado ou não? Enfim, quais memórias são valorizadas e quais são deixadas ao esquecimento? Entre as inúmeras perguntas suscitadas pelo instrumento do tombamento, o presente artigo busca discutir o dever de preservar por parte da administração pública e toma o incêndio ocorrido no Museu Nacional em setembro de 2018 como exemplo do descumprimento do dever de proteger o patrimônio por parte do Estado tendo como marco teórico os artigos 17 e 19 do referido decreto, bem como os artigos 215 e 216 da Constituição Federal de 1988. Será utilizado o método dedutivo, além da utilização de referências bibliográficas para o desenvolvimento do tema em questão.

PALAVRAS-CHAVE: Tombamento; Estado; Museu Nacional.

\section{REFERÊNCIAS:}

CUREAU, Sandra. O patrimônio cultural brasileiro e seus instrumentos de proteção. In: MARQUES, Cláudia Lima; MEDAUAR, Odete; SILVA, Solange Teles da. 
Personalidade Acadêmica Homenageada:

Raymundo Juliano Feitosa (Universidade Federal do Rio Grande do Norte - UFRN)

(coord.). 0 novo direito administrativo, ambiental e urbanístico: estudos em homenagem à Jacqueline Morand-Deviller. São Paulo: Revista dos Tribunais, 2010.

DI PIETRO, Maria Sylvia Zanella. Direito administrativo. 25 ed. São Paulo: Atlas, 2012.

Direito administrativo. 28 ed. São Paulo: Atlas, 2015.

FIGUEIREDO, Lúcia Valle. Curso de direito administrativo. São Paulo: Malheiros, 2008.

GASPARINI, Audrey. Tombamento e transferência do direito de construir: dois institutos que se complementam. In: FERNANDES, Edésio; ALFONSIN, Betânia (coord.). Revisitando o instituto do tombamento. Belo Horizonte: Fórum, 2010.

JUSTEN FILHO, Marçal. Comentários à lei de licitações e contratos administrativos. 14 ed. São Paulo: Dialética, 2010.

MEIRELLES, Hely Lopes. Direito administrativo brasileiro. 33 ed. São Paulo: Malheiros, 2007.

MIRANDA, Marcos Paulo de Souza. Tutela do patrimônio cultural brasileiro. Belo Horizonte: Del Rey, 2006.

MORAES DA COSTA, MARLI; DIEHL, RODRIGO CRISTIANO. Em busca do vale encantado na era da globalização: O papel das políticas públicas na consolidação da cidadania. Revista Jurídica - Unicuritiba. Vol.2 n35, 2014. 